\title{
On Psychological and Pedagogical Aspects of Human Interactions with the Environment in the Interests of Sustainable Development
}

\author{
Victor Panov \\ Laboratory of Ecopsychology of Development and Psychodidactics \\ Psychological Institute of Russian Academy of Education \\ 9-4 Mokhovaya str. \\ Moscow, Russian Federation 125009 \\ E-mail: ecovip@mail.ru
}

\begin{abstract}
The article describes some psychological and pedagogical aspects of human interactions with the environment in the interests of sustainable development. The emphasis is placed on the fact that the implementation of the Sustainable Development Strategy requires active use of ecological consciousness. The difference between the goals of traditional environmental education and the goals of education for sustainable development is shown.
\end{abstract}

Keywords-sustainable development strategy; psychology; ecological consciousness; education for sustainable development

\section{INTRODUCTION}

The world community's concern with global environmental problems is most clearly expressed, as we know, in the Declaration on Sustainable Development of human civilization and our planet as people's habitat, as well as in the following UN Documents [1] [2] [3].

The main idea and the key requirement of the Sustainable Development Strategy is the awareness that modern human civilization is rapidly moving along the multi-channel path of self-destruction. Why did I use the term "multi-channel path"? I did it because it is not just about saving the planet as an ecosystem and as the mankind's habitat. It is also about the preservation of human as a biological species and as a phenomenon of nature, for the self-destruction of the mankind goes on, in fact, at all the levels of its activities and life:

- at the biological level - as a tendency to violate the natural gene pool of the mankind, which is caused not only by the ecologically unfavorable factors of the environment, but also by the massive spread of drugs, alcoholism as well as by genetically modified food products and experiments with biological weapons;

- at the economic level - as a growing gap between the rich and the poor, both in developed and developing countries;
- at the social level - as the stressfulness of the social environment: from aggression and violence in the family and at school to interethnic and interstate aggression;

- at the international level - as the global arms race, constantly threatening that local military conflicts may turn into the third world war with the use of nuclear weapons and other weapons of mass destruction;

- at the cultural level - by cultivating consumer attitudes towards people and environment, by destroying the diversity of cultural heritage, by propagating violence in all its forms, which leads to the devaluation of spiritual values;

- at the educational level - as the discrepancy between teaching technologies and the inherent mechanisms of human development, which is manifested in different forms of didactogeny.

At the same time, unfortunately, the general content of education in our country is still focused on the economic, not on the ecological paradigm of the human civilization development.

Despite the progressivity and the relevance of the Sustainable Development Strategy, it is easy to see that its strategic principle of solving economic, social and environmental problems is based on the same anthropocentric position that led to global social inequality and ecological crisis: the main goal is to satisfy people's needs.

So, it's not surprising that when summing up the results achieved after 20 years since the approval of the Sustainable Development Strategy, called "RIO + 20", in spite of all the beautiful as well as socially and economically important declarations of this document, we have to admit that things haven't budged an inch [4].

In addition to political and economic reasons for such a disappointing outcome of the Sustainable Development 
Strategy, there are also pedagogical and psychological ones. Let us dwell on them in detail.

\section{PSYCHOLOGY OF ENVIRONMENTAL CONSCIOUSNESS IN THE CONTEXT OF SUSTAINABLE DEVELOPMENT}

As noted, the experience of the past decades shows that the attempts to halt the global ecological catastrophe by economic and political measures taken by separate groups of people and even countries do not bring the expected success. Psychologically, the most important reason for this is that the mass consciousness is based on a consumer attitude towards nature, human nature and the planet as a whole.

In the psychological aspect, it is also important to note that in the public consciousness the search for the solution of the environmental problems follows the same logic that led to their emergence, and therefore, in respect of ecology and psychology, has already compromised itself. According to this logic, the ecological balance that was disturbed through people's irrational actions must be recovered through people's efforts, too.

However, the question then arises: what is the guarantee that the human society, trying to recover the ecological balance between people and environment, won't disturb it again, but in the "opposite" direction? After all, the way of thinking remains the same: the human society is still opposed to the environment as a subject of their actions and the object of their reflections. Even when people want "to preserve nature for future generations".

As a result of these good intentions, the "pendulum" of the ecological crisis can swing in the opposite direction. In order to avoid such a situation, people must change their idea of the relationships between Man and Nature; their way of thinking and, accordingly, their ecological consciousness must change.

Therefore, the psychological roots of the environmental crisis are much deeper and more serious. They should be sought in the laws of the formation of human thinking and consciousness [5] [6] [7] [8].

The necessary condition for such a change in people's consciousness is the adoption of the so-called ecological imperative as a guide to action. Ecological imperative is such a type of interaction with nature that implies that "only what doesn't disturb the ecological balance existing in the nature is correct and allowed" [9].

Most often, the ecological consciousness is considered as the consciousness of a man who is logically opposed to nature (natural environment). At the same time, man's ecological consciousness, on the one hand, performs a reflective function in relation to the "natural world" in which man lives and acts. On the other hand, the ecological consciousness expresses man's attitude towards the "natural world" at the level of society and at the level of an individual. Finally, it performs a regulatory function, mediating the activity of a person in relation to the "natural world" [10] [11] [12].
S. D. Deryabo and V. A. Yasvin distinguish three types of ecological consciousness: archaic (consciousness of primitive people), anthropocentric and ecocentric ones [13]. The main feature of the anthropocentric consciousness is the priority of human pragmatic interests over the regularities of development of natural ecosystems. By contrast, the ecocentric type of consciousness is characterized by the priority of ecologically-oriented values and meanings of human interactions with the natural world. As these authors show, it is the anthropocentric ecological consciousness that dominates nowadays and permeate all the key spheres of human activity: economic, political, educational, etc. However, it is clear that the actual ecological consciousness includes both anthropocentric and ecocentric components.

Despite there are diverse approaches to definition and study of the ecological consciousness, they are united by a common methodological position that is characteristic to different researches dealing with the ecological consciousness and implements the main principles of the gnosiological (subject-object) paradigm of human interactions with the natural world. According to this paradigm, man always opposes the environment [14] [15] [16].

Another feature of ecological consciousness studies in the framework of the gnosiological paradigm is the fact that the definition of ecological consciousness is built on the basis of ecological knowledge, i.e. ecology in a broad sense. Figuratively speaking, the essence of this knowledge can be formulated as follows: man must transform nature for his own purposes, but with an eye to the ecological boomerang effect, because nature mutilated by human activity may "take vengeance" on people. This means that the problem of ecological consciousness has been most often considered within the opposition "ecological - non-ecological".

Our researches of psychological conditions for formation of ecological consciousness in interaction with natural objects have shown that there is one more approach to ecological consciousness, that allows us to identify the nature-centered type. The initial premise of this approach is the assertion that Man is the substantial part of Nature. So, both man and natural and anthropogenic environments turn out to be different manifestations of the universal natural entity that is considered as an ability for self-generation-selfpreservation-self-destruction (the principle of form generation of natural forms of being). The system "man natural environment" is understood as a single subject of joint development on the basis of universal principles of being. This means that we talk about such principles that should be transcendental in relation both to "Man" and "Nature" - as components of the "man - the surrounding (natural, social) environment" system [17].

In this regard, the problem of ecological consciousness is inseparably connected, on the one hand, with the understanding of the very phenomenon of "man", his relation to the world of nature and his own nature, and, on the other hand, with the understanding of human culture that provides conditions and tools for formation and development of public and individual ecological consciousness. 
Using and supplementing the above-mentioned types of ecological consciousness, proposed by S. D. Deryabo and V. A. Yasvin, we find it reasonable to single out the following stages of the evolution of the "Man - Nature" system and, accordingly, the following types of ecological consciousness:

- syncretic (archaic), when man didn't distinguish himself from the environment (nature) and wasn't opposed to it as to an object of transformation in accordance with his own survival goals;

- anthropocentric, when human consciousness counterposed man to his environment and, moreover, viewed it as an object of active transformation in accordance with the "human" survival goals. It was during this period when man "forgot" about his unity with nature, which eventually led to the ecological crisis on the Earth;

- ecocentric, when man begins to understand that he and the natural environment surrounding him are parts of a single "Man-Nature" ecosystem; therefore, his environment is a sphere of his co-existence with nature and is valuable as it is. Moreover, the environment may have its own laws of development, which cannot be ignored by people when planning their activities;

- synergetic (nature-centered), when man realizes his unity with nature as the unity of principles of his own development with the universal principles of natural development. Man is the substantial part of nature. So, both man and natural and anthropogenic environments turn out to be different manifestations of the universal natural entity that is considered as an ability for self-generation-self-preservation-selfdestruction. The "Man - Nature" system is understood as a single subject of joint development that is formed through the interaction between man and natural environment, and based on the universal principles of being. So, that we talk about such principles that should be transcendental in relation to both "Man" and "Nature" - as components of the "Man - the surrounding (natural, social) environment" system [18] [19].

Thus, we can conclude that different types of formation of ecological consciousness correspond to different research paradigms that are distinguished by postulating gnosiological, ontological or transcendental grounds for definition of consciousness as an object and a subject of research.

This raises a new question and a new problem of ecological consciousness: what learning technologies can prepare students (in subject, personal and culturological ways) for successful implementation of sustainable development?

\section{THE PEDAGOGICAL ASPECT OF IMPLEMENTATION OF THE SUSTAINABLE DEVELOPMENT STRATEGY}

As stated in one of the documents on the implementation of the Sustainable Development Strategy, education is the essential tool for sustainable development [20]. Only through education both person and society can fully discover their potential. It is an indispensable factor for changing people's attitudes so that they have the opportunity to assess and solve the problems facing them, for forming values, skills and encouraging behavior compatible with the Sustainable Development Strategy.

In 2005, the United Nations Economic Commission for Europe adopted the Strategy for Education for Sustainable Development. It declares that instead of transferring knowledge and skills necessary for existence in modern society is is important to prepare students to act and live in a rapidly changing environment, to participate in social development planning, to foresee the consequences of one's actions, including the sphere of sustainability of natural ecosystems and social structures [21]. A similar document was adopted in Russia, too [22].

Ecological education and enlightenment have more than half a century of history. Before speaking about the pedagogical aspect of the implementation of the Sustainable Development Strategy, it is necessary to determine what is the difference between the traditional environmental education and the education for sustainable development. This question has been discussed by different authors (e.g., [23]).

At this stage, we can draw only one conclusion: so many specialists - so many opinions on this issue. Therefore, without going into the discussion, I'll express my point of view.

The main difference between the education for sustainable development and the traditional environmental education is its purpose. For the traditional environmental education, the principal goal was to obtain and disseminate environmental knowledge in order to form the ecological culture. That is why the essential factors for such education have been ecological knowledge and skills. Therefore the technologies of the traditional environmental education:

- reproduce in their content and methods ecological knowledge and skills as a projection of the scientific discipline "Ecology" on the content of Geography, Biology and other school subjects. As a result, student's environmentally-oriented cognitive sphere is, as a rule, detached from his/her personal and moral (value) spheres and therefore doesn't function as an ecological imperative of his/her perception, feeling, thinking and behavior;

- traditionally reproduce the subject-object type of interaction in their didactic principles. It is characteristic of the natural-science paradigm, where the role of the subject and, consequently, the right to decide the fate of Planet and Nature is given to Man which features the anthropocentric type of ecological consciousness;

- try to form a value attitude towards nature by teaching "what is good and what is bad", that is, what is ecological and what is non-ecological, which 
causes socially approved answers when the maturity of ecological consciousness is tested [24] [25] .

The analysis of these features shows that the traditional technologies of environmental education can't provide for the formation of ecological consciousness of ecocentric and, especially, nature-centered types, because ecological knowledge becomes a basis of ecological consciousness only when it leads to environmentally friendly actions.

Unlike that of the traditional environmental education, the main goal of education for sustainable development should be to develop people's abilities to cooperate with nature and with other people at different levels and in different types of social, economic and environmental interactions. At the same time, environmental knowledge and skills should be used not as an object of learning, but as a means of development of these abilities - first of all, the ability to interact with "the others" on equal terms, even if "the others" belong to different biological species. And this requires psychological knowledge about the development of communicative abilities in interaction with other people, with other living creatures and with the natural environment in general [26] [27]. Moreover, we talk about development of such communicative interactions that contribute to cooperation with "the others", i. e. form a cumulative subject (polysubject) of joint activity and, finally, a subject of coevolutionary development of the mankind and the planet [28] [29].

In other words, the task that comes to the fore is to shape child's planetary (global) self-awareness of him-/herself as a subject who thinks and acts with regard to the whole planet. This means that the education for sustainable development should mould the ecological consciousness as the psychological basis of ecological culture. In order to achieve this goal, it must teach the younger generation:

- to see the world, other people and oneself from the ecological point of view;

- to think environmentally and to make environmentally friendly decisions within different ecosystems of different size: "My family and Me", "My home and Me", "My city and Me", "My country and Me", "My planet and Me";

- to behave eco-friendly in relation to the environment, to other people and to oneself in everyday life, at school, at work, at leisure;

- to give priority to environmental values in any activity.

So, the logically-based grounding of the educational culture must be re-oriented to the logic and content of sustainable development [30].

\section{CONCLUSION}

It is important to note that the ideas of sustainable development of human society and nature have a much broader context than "direct" solution of environmental problems. Concern for people is proclaimed as its fundamental principle, which, of course, implies taking care of the environment as people's habitat. At the same time, special attention should be paid to caring for man as a biological, social, spiritual and psychological phenomenon, and therefore - to the ecofriendliness of both natural and social environments in its various forms: family, education, media and the Internet, work and cultural heritage, etc.

In the psychological aspect, the priority of the education for sustainable sevelopment should be ecofriendliness of ecological consciousness and culture of the younger generation.

And, finally, the most important point: in order to implement the Strategy for Sustainable Development, the social status of the education for sustainable development must be changed. From an independent pedagogical discipline, it must turn into a social means of ecological transformation of human society into a global subject of practical implementation of the Strategy for Sustainable Development.

\section{ACKNOWLEDGEMENT}

The work was carried out within the state assignment of Psychological Institute of RAE.

\section{REFERENCES}

[1] The Future We Want Rio+20 Outcome Document. URL//https://documents-ddsny.un.org/doc/UNDOC/LTD/N12/436/88/PDF/N1243688.pdf?OpenE lement.

[2] Report of the United Nations Conference on Environment and Development Rio de Janeiro, 3-14 June 1992. URL// https://documents-dds-ny.un.org/doc/UNDOC/ GEN/N92/836/55/PDF/ N9283655.pdf? OpenElement.

[3] Rio declaration on environment and development, 1992. URL // http://www.un.org/ru/documents/decl_conv/declarations/riodecl.shtm 1

[4] The Future We Want Rio+20 Outcome Document. URL//https://documents-ddsny.un.org/doc/UNDOC/LTD/N12/436/88/PDF/N1243688.pdf?OpenE lement.

[5] S.D. Deryabo, V.A. Yasvin. "Ecological pedagogics and psychology". Rostov-on-Don: Phoenix, 1996.

[6] V.I. Medvedev, A.A. Aldasheva. "Ecological consciousness". Textbook. Moscow: Logos, 2001.

[7] V.I. Panov. "Ecological thinking, consciousness, responsibility". V Congress of the Russian Psychological Society 14-18 February (Moscow, 2012). Procedia - Social and Behavioral Sciences, Volume 86, 10. October 2013, Pages 379-383. DOI: 10.1016/j.sbspro.2013.08.583.

[8] V.I. Panov. "Psychological and pedagogical aspects of environmental consciousness". Pedagogy, 2015, 5, pp. 59-70.

[9] S.D. Deryabo, V.A. Yasvin. "Ecological pedagogics and psychology". Rostov-on-Don: Phoenix, 1996.

[10] Ibid.

[11] V.I. Panov. "Ecological thinking, consciousness, responsibility". V Congress of the Russian Psychological Society 14-18 February (Moscow, 2012). Procedia - Social and Behavioral Sciences, Volume $86, \quad 10 . \quad$ October 2013, pp. 379-383. DOI: 10.1016/j.sbspro.2013.08.583

[12] V.I. Panov. "Psychological and pedagogical aspects of environmental consciousness". Pedagogy, 2015, 5, pp. 59-70. 
[13] S.D. Deryabo, V.A. Yasvin. "Ecological pedagogics and psychology". Rostov-on-Don: Phoenix, 1996.

[14] V.I. Panov. "Ecological thinking, consciousness, responsibility". V Congress of the Russian Psychological Society 14-18 February (Moscow, 2012) // Procedia - Social and Behavioral Sciences, Volume 86, 10. October 2013, pp. 379-383. DOI: 10.1016/j.sbspro.2013.08.583

[15] V.I. Panov. "Psychological and pedagogical aspects of environmental consciousness". Pedagogy, 2015, 5, pp. 59-70.

[16] V.I. Panov. "Ecological thinking, consciousness, responsibility". V Congress of the Russian Psychological Society 14-18 February (Moscow, 2012). Procedia - Social and Behavioral Sciences, Volume 86, 10. October 2013, pp. 379-383. DOI: 10.1016/j.sbspro.2013.08.583.

[17] Ibid.

[18] S.D. Deryabo, V.A. Yasvin. "Ecological pedagogics and psychology". Rostov-on-Don: Phoenix, 1996.

[19] V.I. Panov. "Ecological thinking, consciousness, responsibility". V Congress of the Russian Psychological Society 14-18 February (Moscow, 2012). Procedia - Social and Behavioral Sciences, Volume 86, 10. October 2013, Pages 379-383. DOI: 10.1016/j.sbspro.2013.08.583.

[20] Rio declaration on environment and development, 1992. URL // http://www.un.org/ru/documents/decl_conv/declarations/riodecl.shtm 1.

[21] Roadmap for Implementing the Global Action Programme on Education for Sustainable Development. URL// http://unesdoc.unesco.org/images/0023/002305/230514e.pdf.

[22] National Strategy education for sustainable development In Russian federation. URL// http://www.unece.org/fileadmin/DAM/env/esd/Implementation/NAP/ RussianFederationNS.r.pdf

[23] "Ideas of sustainable development in school". Domestic and foreign experience in adapting the ideas of sustainable development to the subject areas of general education: monograph / ed. A.N. Zakhlebnyio and, E.N. Dzyatkovskaya. Moscow: Center for Education and Ecology, 2017.

[24] V.I. Panov. "Ecological thinking, consciousness, responsibility". V Congress of the Russian Psychological Society 14-18 February (Moscow, 2012). Procedia - Social and Behavioral Sciences, Volume 86, 10. October 2013, Pages 379-383. DOI: 10.1016/j.sbspro.2013.08.583

[25] V.I. Panov. "Psychological and pedagogical aspects of environmental consciousness". Pedagogy, 2015, 5, pp. 59-70.

[26] Ibid.

[27] V. Panov. "From Environmental Psychology to Subject-Environment Interactions". Proceedings of the 2017 2nd International Conference on Contemporary Education, Social Sciences and Humanities. (ICCESSH 2017). Part of the series ASSEHR. Moscow, Russia. V.124. 1135-1139. // p. URL: file:///C:/Users/1/Downloads/ES9154.pdf.

[28] V.I. Panov. "Ecological thinking, consciousness, responsibility". V Congress of the Russian Psychological Society 14-18 February (Moscow, 2012). Procedia - Social and Behavioral Sciences, Volume 86, 10. October 2013, pp. 379-383. DOI: 10.1016/j.sbspro.2013.08.583

[29] V.I. Panov. "Psychological and pedagogical aspects of environmental consciousness". Pedagogy, 2015,5, pp. 59-70.

[30] Yu.V. Ivlev, V.Yu. Ivlev, M.L. Ivleva. "Logical-argumentative basics of educational culture". Proceedings of 4th International Conference on Education, Language, Art and Intercultural Communication (ICELAIC 2017) Part of the series ASSEHR. Moscow, Russia. Pp. pp. 173-177. 